\title{
Evaluation of Proposed Amended Names of Several Pseudomonads and Xanthomonads and Recommendations
}

\author{
N. W. Schaad, A. K. Vidaver, G. H. Lacy, K. Rudolph, and J. B. Jones
}

First author: USDA-ARS-Foreign Disease Weed Science Research Unit, 1301 Ditto Avenue, Fort Detrick, MD 21702-5023; second author: University of Nebraska, Plant Pathology Department, Lincoln 68583-0722; third author: VPI \& SU, Department of Plant Pathology, Physiology, and Weed Science, Blacksburg, VA 24061-0330; fourth author: Institute fur Pflanzenpathol, University of Goettingen, Goettingen, 37077 Germany; and fifth author: University of Florida, Department of Plant Pathology, Gainesville 32611-0680.

Accepted for publication 4 November 1999.

\begin{abstract}
Schaad, N. W., Vidaver, A. K., Lacy, G. H., Rudolph, K., and Jones, J. B. 2000. Evaluation of proposed amended names of several pseudomonads and xanthomonads and recommendations. Phytopathology 90:208-213.

In 1980 , over $90 \%$ of all plant-pathogenic pseudomonads and xanthomonads were lumped into Pseudomonas syringae and Xanthomonas campestris, respectively, as pathovars. The term "pathovar" was created to preserve the name of plant pathogens, but has no official standing in nomenclature. Proposals to elevate and rename several pathovars of the genera Pseudomonas and Xanthomonas to the rank of species has caused great confusion in the literature. We believe the following changes have merit and expect to adopt them for publication in a future American Phytopathological Society Laboratory Guide for Identification of Plant Pathogenic Bacteria. Upon review of published data and the Rules of The International Code of Nomenclature of Bacteria, we make the following

ringae pvs. phaseolicola and glycinea to $P$. savastanoi pvs. phaseolicola and glycinea, respectively, because both pathogens are easily differentiated phenotypically from pv. savastanoi and convincing genetic data to support such a change are lacking. We accept the elevation of $P$. syringae pv. savastanoi to the rank of species. We accept the reinstatement of $X$. oryzae to the rank of species with the inclusion of X. oryzicola as a pathovar of $X$. oryzae and we accept the species $X$. populi. We agree with the elevation of the pvs. cassavae, cucurbitae, hyacinthi, pisi, and translucens to the rank of species but not pvs. melonis, theicola, and vesicatoria type B. We recommend that all type A $X$. vesicatoria be retained as $X$. campestris pv. vesicatoria and all type B $X$. vesicatoria be named $X$. exitiosa. We reject the newly proposed epithets arboricola, bromi, codiaei (poinsettiicola type B), hortorum, sacchari, and vasicola and the transfer of many pathovars of $X$. campestris to $X$. axonopodis. The proposed pathovars of $X$. axonopodis should be retained as pathovars of $X$. campestris.
\end{abstract} recommendations. We reject the proposal to change the name of $P$. sy-
Due to a general misconception among plant pathologists about acceptance of proposals to change the nomenclature of bacteria, we provide an analysis of several recently proposed names supported by The American Phytopathological Society (APS) Bacteriology Committee. Major changes in nomenclature began in 1973, when the Judicial Commission of the International Committee on Systematic Bacteriology (ICSB) proposed a revision in the nomenclature of bacteria (17) and appointed an Ad Hoc Committee to prepare a list of currently valid names of plant-pathogenic bacteria that were adequately described. This list of names was compiled and published in 1980 (4) by members of the Bacteriology Taxonomy Committee of The International Society of Plant Pathology and included in the Approved Lists of Bacterial Names (22). Discussing the validation of new names in the preface to the Approved Lists of Bacterial Names, V. B. D. Skerman states that "New names are not approved by the ICSB. They are validated as new names as a result of conformity with the Rules of Nomenclature. The ICSB did not approve the names in the approved list. The ICSB simply approved of the listing of the names in lists with a new starting date for the operation of the rule of priority of naming." A list of all names of plant-pathogenic bacteria that have been validly published from 1864 to 1995 is available (40). Because there is no process whereby newly proposed names of bacteria are "approved" or accepted for universal use by the scientific community, it is the purpose of this paper, with the support of the

Corresponding author: N. W. Schaad; E-mail address: schaad@ nicfcrf.gov

Publication no. P-2000-0114-030

(C) 2000 The American Phytopathological Society
APS Bacteriology Committee, to clarify the various different names being used for several pseudomonads and xanthomonads.

Because few plant-pathogenic species of bacteria could be differentiated by classical techniques and biochemical tests when the Approved List of Bacterial Names was published (22), most species were lumped together under an infrasubspecific subdivision as pathovars (a temporary name with no taxonomic rank and no nomenclatural standing) under a very few species (4). This was done as a compromise according to the International Code of Nomenclature in order to preserve the name of economically important plant pathogens $(38,39)$. The organisms were to be automatically elevated to their original proper species rank once appropriate phenotypic and genetic data were obtained and validly published. Previously, most species of plant-pathogenic bacteria were named on the basis of the host of origin and, in many cases, included very little genetic and phenotypic data. Designations of infrasubspecific names are not covered by the Rules of the Code of Nomenclature $(17,23)$. Of the fluorescent group of plant-pathogenic pseudomonads, only Pseudomonas aeruginosa, $P$. agaricae, $P$. asplenii, P. cichorii, $P$. (Burkholderia) glumae, $P$. marginalis, $P$. tolaasii, $P$. viridiflava, $P$. woodsii, and $P$. syringae were retained $(4,22)$. Of these, only $P$. syringae and $B$. glumae are considered major pathogens. Over $90 \%$ of all plant-pathogenic Pseudomonas species were lumped into $P$. syringae as pathovars. The only species of Xanthomonas included on the 1980 list were $X$. albilineans, $X$. ampelina (since reclassified as Xylophilus ampelinis [36]), X. axonopodis, $X$. campestris, and $X$. fragariae $(4,22)$. The majority of xanthomonads were grouped with the type species $X$. campestris.

Although considerable data have accumulated on numerical analyses $(29,34)$, serology $(2,19,28)$, membrane protein profiles $(28$, $32,33)$, and DNA analyses $(1,7,8,9,12,13,14,18,20)$ of Xanthomonas 
and Pseudomonas spp. since 1980, there have been few pathovars that have been elevated to the rank of species. However, recent proposals to place several pseudomonads into new genera, elevate several pathovars of the genera Pseudomonas and Xanthomonas to the rank of species, and rename several of them have been published $(7,30)$. We believe the accumulated data warrant elevation and acceptance of most of these taxa, but not some newly proposed epithets and especially not some well-described, historically significant pathogens. We remind colleagues that proposals are simply proposals; they are not mandated by any international rule. Discussions and analyses are needed before proposed names become accepted and universally used. Many scientists believe that once a taxonomic proposal is published in the International Journal of Systematic Bacteriology (now published by The Society for General Microbiology in England) the name(s) must be accepted and used. This is not, as stated by V. B. D. Skerman, the case (22). Names of plant pathogens are extremely important to national and international trade, scientists and others who ship cultures, and even funding agencies and organizations. The recent use of the proposed names X. axonopodis pv. phaseoli (for X. campestris pv. phaseoli or $X$. phaseoli) and $P$. savastanoi pv. phaseolicola (for $P$. syringae pv. phaseolicola) in some journal papers and in kits developed by some plant disease diagnostic companies (Viz. D-Genos kits distributed by AES Laboratories, Combourg, France) illustrates the type of confusion this problem is causing in use and in recognition of pathogen names.

Pseudomonads. Gardan et al. (7) proposed to change the name of $P$. syringae pv. phaseolicola, causal agent of halo blight of bean, and $P$. syringae pv. glycinea, causal agent of bacterial blight of soybeans, to $P$. savastanoi pv. phaseolicola and $P$. savastanoi pv. glycinea, respectively. Based on DNA similarity data and numerical analysis, these authors (7) proposed that $P$. syringae pv. savastanoi be elevated to the rank of species and that the other two highly regulated and widely known pathogens be renamed as pathovars of $P$. savastanoi, the causal agent of olive knot. Their conclusions were, however, based upon single strains of $P$. syringae pvs. phaseolicola and glycinea. In contrast, the authors (7) included over 100 strains of pv. savastanoi. We do not believe that such major taxonomic changes should be made from data derived from analysis of single strains. Furthermore, no data for reciprocal DNA similarities were included, experiments were not repeated, and only limited phenotypic tests were included. Other studies using large numbers of strains of these two pathogens show that the organisms are easily differentiated from pv. savastanoi on the basis of several additional phenotypic tests (15) and serology (19). Whereas $P$. syringae pv. phaseolicola produces levan; utilizes trigonelline, $\beta$-hydroxybutyrate, malonate, and quinate; and produces a toxin, $P$. syringae pv. savastanoi does not. In contrast, $P$. syringae pv. savastanoi utilizes mannitol, inositol, sorbitol, DLglycerate, and L-lactate and produces indoleacetic acid, whereas $P$. syringae pv. phaseolicola does not. Similar differences occur between pvs. glycinea and savastanoi (15). Ovod et al. (19) showed that the lipopolysaccharide O-chains of 25 strains of $P$. syringae pv. phaseolicola were serologically identical and very distinct from 12 strains of $P$. syringae pv. savastanoi. These collective chemotaxonomic and phenotypic data show the two organisms to be easily differentiated independent of host reaction. These results, together with the use of limited and preliminary DNA similarity data (7), form the basis upon which we reject the transfer of pvs. phaseolicola and glycinea to the species $P$. savastanoi (Table 1$)$. The expanded DNA similarity data of Gardan et al. (8) supports the earlier proposed elevation of $P$. syringae pv. savastano $i$ to the rank of species (7). They reported a mean relative DNA similarity of $81.1 \%( \pm 9.9 \%)$ of 10 strains of $P$. syringae pv. syringae to a strain of $P$. syringae pv. syringae, but only $50.5 \%( \pm 4.5 \%)$ of 20 strains of $P$. syringae pv. savastanoi to the same strain of $P$. syringae $\mathrm{pv}$. syringae. Reciprocal results using labeled DNA of $P$. syringae pv. savastanoi showed a mean similarity of $81.2 \%$ with $P$. syringae pv. savastanoi and only $49.0 \%$ with $P$. syringae pv. syringae. The authors (8) did not include $P$. syringae pv. phaseolicola or pv. glycinea in these studies. With major phenotypic (15) and genetic (8) differences between pv. savastanoi and $P$. syringae, we concur with elevating pv. savastanoi to the rank of species (7). However, we believe that adequate differentiation exists (discussed above) between pvs. savastanoi and phaseolicola and pv. glycinea to exclude them as pathovars of $P$. savastanoi. We, therefore, propose they be retained as pathovars of $P$. syringae until adequate data are available for their proper elevation to the rank of species. A recent proposal (9) to name P. syringae pvs. phaseolicola and glycinea as well as 14 other pathovars of $P$. syringae as pathovars of $P$. amygdali causes additional confusion in plant pathology literature and should not be accepted, because the appropriate number of strains were not examined with pairwise DNA similarity assays.

Xanthomonads. Several new taxonomic studies have been made of xanthomonads and two major reclassification schemes suggested $(30,31)$. We acknowledge and appreciate the effort of Vauterin et al. $(30,31)$ to provide and assemble the necessary data for proposing the elevation of several pathovars to the rank of species. The strength of the two proposals is that they include DNA similarity data on over 180 xanthomonad strains. However, interpretation of the DNA similarity data is difficult because details in the methods are lacking. Most importantly, it is not clear what strains were labeled to obtain the DNA binding values (\%), which method was used for the assays (spectrophotometric or labeled DNA), which similarity assays were performed by the authors or which were compiled from literature, and no reciprocal tests were included. In either event, this required considerable effort. The results presented by Vauterin et al. (30) are generally in agreement with previous results (14) showing that the type species, X. campestris pv. campestris, has DNA similarity values of only $26 \%$ or less with over 20 named pathovars including vesicatoria, phaseoli, glycines, vignicola, poinsettiicola, begoniae, manihotis, oryzicola, juglandis, carotae, and pelargonii. Furthermore, Hildebrand et al. (14) reported that these pathovars showed DNA similarities to each other of less than $70 \%$, except for pvs. glycines, phaseoli, and vignicola, which were 77 to $93 \%$ related. These results are different from those showing pvs. glycines, vignicola, and phaseoli to be indistinguishable from pv. begoniae by DNA similarities (30). For DNA similarity assays, a species is generally defined as having $70 \%$ or greater relatedness (35); therefore, any strain with a relatedness of less than $70 \%$ would be accepted as a different species. In contrast, Vauterin et al. (30) chose to use a relatedness of only $60 \%$ as their definition of a species. We prefer the widely accepted $70 \%$ value. Pathovars vesicatoria, malvacearum, manihotis, oryzae, oryzicola, phaseoli, sojensis, translucens, and begoniae were shown earlier to be differentiated quite easily from each other and from $X$. campestris pv. campestris on the basis of serology and membrane proteins (28). Within the work by Thaveechai and Schaad (28), the legends for their Figures 5 and 6 showing clear differences between these pathovars, including $X$. campestris pv. phaseoli, were mistakenly reversed by the typesetter. This error is easily overlooked by the casual reader.

We accept the reinstatement of pv. oryzae to the rank of species with the inclusion of $X$. oryzicola as a pathovar of $X$. oryzae (27). The proposed $X$. populi (21) is accepted. Vauterin et al. (30) designated 20 DNA similarity groups among the xanthomonads and proposed that each group serve as a species. Several new epithets were proposed. However, the DNA similarity values of pathovars within several of the proposed species do not meet the definition of a species $(24,35)$. We enthusiastically support the formal proposal to restore several pathovars to the rank of species including $X$. cassavae and $X$. translucens (Table 2). We see no reason to list pvs. aberrans, armoraciae, campestris, barbareae, incanae, and raphani as pathovars of $X$. campestris, because they already exist (4, $38,40)$. Similarly, we do not agree with the transfer of the remaining pathovars of $X$. campestris to the species $X$. axonopodis (30). 
In contrast to the slow growth of $X$. axonopodis on nutrient agar, these pathovars grow normally compared with $X$. campestris. These should remain in the type species $X$. campestris until adequate data are available as proposed in $1980(4,38,39)$, or they should be placed into a new "repository" species, as discussed below. The temporary placement of these pathovars in another existing species epithet such as $X$. axonopodis only creates additional confusion.

We accept the elevation of $X$. campestris pv. vesicatoria type B strains to the rank of species (30). The type B strains clearly represent a separate taxon $(25,30)$. However, the epithet vesicatoria should be retained for the type A strains, which represent those first described by Doidge in 1920 (3), following Rule 24b (23). Since the same epithet cannot be used for two different organisms (pathovar and species), according to Rule 12b (23), we suggest that the type B strains represented by those described as exitiosa by Gardner and Kendrick in 1921 (10), be named X. exitiosa and the A strains be retained as $X$. campestris pv. vesicatoria until additional data are available.

Some other pathovars Vauterin et al. (30) proposed to elevate to the rank of species should not be elevated, as discussed below. To avoid unnecessary changing of names and resulting confusion, we concur, as suggested previously $(4,38,39)$, that all pathovars of $X$. campestris be retained as pathovars until adequate data are available to elevate a particular pathovar to the rank of species or subspecies. We would prefer to remove all other pathovars from $X$. campestris as proposed by Vauterin et al. (30) and put them into another "holding" or "repository" species. (The artificial taxon, $X$. phyllovora, is discussed below.) However, changing names while waiting for appropriate data is premature and will cause additional confusion. Therefore, we recommend that any pathovar included in the 1980 List of Names (4) be retained until data are available to elevate it to the rank of species. When a pathovar is to be elevated, based upon appropriate data, the name of the oldest recognized pathovar included in the 1980 list of names (4) should be retained according to Rule $24 \mathrm{~b}$ (23).

Based on DNA similarities determined by the S1 nuclease digestion technique (16), we agree with Vauterin et al. (30) in the elevation of pvs. cassavae, cucurbitae, pisi, vesicatoria (type B or exitiosa group only, as discussed above), hyacinthi, and translucens (including pvs. and f. spp. translucens, undulosa, secalis, hordei, phleipratensis, and cerealis) to the rank of species. However, the proposed $X$. translucens is a very heterogeneous species. For example, based on an experimental error of $11 \%$ (30), 10 of 23 strains tested had DNA similarity values of less than $67 \%$ to $X$. translucens.
DNA similarity values ranged from lows of $58 \%$ for pv. translucens strain LMG 5259, 61\% for the single strain of pv. phleipratenis, and $66 \%$ for pv. cerealis strain LMG 679 and undulosa strain LMG 892 to a high of $87 \%$ for pv. undulosa strain LMG 885. Furthermore, other DNA similarity data (G. H. Lacy, unpublished data) show that strains of pvs. phlei, arrhenatheri, and poae have less than $65 \%$ similarity to $X$. translucens. These could represent separate subspecies; however, until additional strains are studied, they should, as stated above, remain as pathovars of $X$. campestris. Similarly, the proposed species $X$. melonis and X. theicola (30) have not been well studied and should remain as pathovars of $X$. campestris until appropriate data are available. The new species epithets bromi and sacchari proposed (30) for two strains each of $X$. campestris pv. graminis and $X$. albilineans, respectively, should not be accepted until additional strains and data are included.

More problematic are the de novo epithets proposed by Vauterin et al. (30) to encompass strains related at the species level including X. arboricola, X. codiaei (poinsettiicola type B), X. hortorum, and $X$. vasicola. We believe this to be a premature decision. The primary intent of the pathovar proposal presented by Young et al. (39) at the International Conference on Plant Pathogenic Bacteria in Angers, France, was to save the epithets of plant-pathogenic bacteria that had not been adequately described phenotypically and, therefore, destined to be left off the 1980 List of Names (4). Acceptance of this temporary infrasubspecific epithet meant that the species name was saved from further use. Furthermore, this meant the name could be easily revived once data became available rather than having to propose a new specific epithet, which could result in further confusion. J. M. Young stated at the 1978 Congress that "At present, use of the term pathovar is informal and not governed by the Code. Nonuniform use by pathologists could lead to extensive synonymy if different names were applied to one pathogen...." For groups of pathovars found to be related at the species level, the consolidated species epithet reasonably should be derived by elevation of the earliest legitimately published pathovar epithet (4), according to Rule 24b (International Code of Nomenclature [23]). Further, creation of new names for long-standing pathogens of great economic importance will cause considerable uncertainty among government regulatory officials, seed companies, and scientists. With regard to the deposition of the epithets in the 1980 Approved List of Names, the following is stated (page 230 in literature citation 22): "The International Society for Plant Pathology is publishing, in the Review of Plant Pathology, a list of pathovars of species which appear in the Approved List of Names. Taxonomists

TABLE 1 . Summary of rejected and retained or suggested names

\begin{tabular}{|c|c|}
\hline Rejected names & Retained or suggested names ${ }^{\mathrm{a}}$ \\
\hline $\begin{array}{l}\text { Pseudomonas savastanoi pvs. savastanoi, phaseolicola, and glycinea (Garden et al., } \\
\text { 1997) }\end{array}$ & $\begin{array}{l}\text { Retain as } P \text {. savastanoi and } P \text {. syringae pvs. phaseolicola and } \\
\text { glycinea }\end{array}$ \\
\hline $\begin{array}{l}\text { Xanthomonas arboricola (Vauterin et al., 1995), with pvs. corylina, juglandis, pruni, and } \\
\text { poinsettiicola type C }\end{array}$ & $\begin{array}{l}\text { Replace with } \underline{X . j u g l a n d i s} \text { pvs. juglandis, corylina, and } \\
\text { pruni }\end{array}$ \\
\hline X. axonopodis (Starr and Garces, 1950), Vauterin et al., 1995, all proposed pathovars b & Retain $\underline{X}$. axonopodis, but not the proposed pathovars \\
\hline X. bromi (Vaute & as pathovar of $X$. campestris \\
\hline X. codiaei (Vauterin et al., 1995) & Retain as X. campestris pv. poinsettiicola type B \\
\hline $\begin{array}{l}\text { X. hortorum (Vauterin et al., 1995), with pvs. hortorum, hederae, pelargonii, and vitians } \\
\text { type B }\end{array}$ & $\begin{array}{l}\text { Replace with } X \text {. hederae pvs. hederae and pelargonii and } \\
\text { retain vitians type B as } X \text {. campestris pathovar }\end{array}$ \\
\hline X. sacchari (Vaute & X. albilineans \\
\hline X. theicola (Uehara et al., 1980), Vauterin et al., 1995 & Retain as $X$. campestris pv. theicola \\
\hline nis, phlei, phleipratensis, and poae (Vauterin et al., 1995 & Retain as pathovars of $X$. campestris \\
\hline holcicola and vasculorum type B & Retain as $X$. campestris pvs. holcicola a \\
\hline X. vesicatoria type B (ex Doidge, 1920), Vauterin et al., 1995 & $\begin{array}{l}\text { Retain } X \text {. campestris pv. vesicatoria for type A strains; we } \\
\text { suggest the epithet exitiosa be considered for type B strains }{ }^{\mathrm{c}}\end{array}$ \\
\hline
\end{tabular}

a Suggested names are in underlined.

${ }^{\mathrm{b}}$ The following proposed pathovars of $X$. axonopodis (30) should be retained as pathovars of X. campestris until sufficient data are available: alfalfae, bauhiniae, begoniae, cajani, cassavae (type B), cassiae, citri, clitoriae, coracanae, cyamopsidis, desmodii, desmodiigangetici, desmodiilaxiflori, desmodiirotundifolii, dieffenbachiae, erythrinae, glycines, lespedezae, malvacearum, manihotis, patelii, phaseoli, phyllanthi, poinsettiicola (type A), rhynchosiae, ricini, sesbaniae, tamarindi, vasculorum (type A), vesicatoria (type A), vignaeradiatae, vignicola, and vitians (type A).

${ }^{c}$ All type A strains of pv. vesicatoria, including the type strain, should be retained in X. campestris. 
clature of Bacteria (23), the oldest legitimate epithet should be retained when two or more taxa of the same rank are united. Because $X$. vasculorum was published first (1893), we suggest that these two bacteria be renamed as pathovars of $X$. vasculorum (i.e., $X$. vasculorum pvs. vasculorum and axonopodis). However, since the epithet vasculorum is maintained for type B strains of X. campestris, it cannot be used as a species epithet (type A strains) according to Rule $12 \mathrm{~b}$. Therefore, we recommend that both type A and B strains of $X$. vasculorum be retained as pathovars of $X$. campestris until their taxonomy is clarified. We reject the axonopodis group as constituted (30) and, to avoid confusion in the literature, we recommend retaining the other 33 pathovars as pathovars of $X$. campestris until additional phylogenetic information has been published clarifying their interrelationships or to place them into a new "repository" species.

Because of their economic and regulatory importance, special mention must be made of $X$. campestris pvs. citri and phaseoli. We reject, for the reasons stated above, inclusion of these bacteria as pathovars of $X$. axonopodis (30). However, we must consider carefully the possibility that these pathovars deserve reinstatement to the species level based upon the information currently available $(6,11,12,33)$. Van der Mooter and Swings (29) and Vauterin et al. (33) have provided additional phenotypic data since Young et al. (37) rejected the proposal of Gabriel et al. (6) to reinstate these pathovars as species. The phenotypic data of Van der Mooter and Swings (29) did not discriminate between pvs. citri and phaseoli, grouping both pathovars into a single phenon including $X$. campestris. Analyses of fatty acids and sodium dodecyl sulfate-polyacrylamide gel electrophoresis protein profiles showed clear differences among groups of xanthomonads causing citrus disease but did not indicate the position of the citrus pathogens in relation to other xanthomonads including pv. phaseoli (33). Genomic fingerprinting (11), restriction fragment length polymorphism analyses (12), and DNA similarity studies (33) of citrus pathogens also supported differences among citrus pathogens but, likewise, did not address relatedness to other xanthomonads or pv. phaseoli. Gabriel et al. (6), using nonpairwise hybridizations of plasmid probes to electrophoresed restriction endonuclease digests of genomic DNA, detected only about $20 \%$ similarity between pv. citri and pvs. campestris, malvacearum, or phaseoli. However, Egel et al. (5) showed by pairwise DNA similarity assays that while pv. citri shares less than $50 \%$ similarity with pv. phaseoli, it has over $90 \%$ DNA similarity with pv. malvacearum. The results of Egel et al. (5) are confirmed in the unpublished data of G. H. Lacy. Although significant new knowledge about pvs. citri and phaseoli have been obtained, lack of similar information about closely related groups makes it possible that premature reinstatement may lead to later confusion should high levels of DNA similarity be discovered with other xanthomonads, especially those with precedence in the literature (i.e., pv. malvacearum). Therefore, following the accepted species definition based on DNA similarity analyses $(24,35)$ and Rule 24 of the International Code of Nomenclature of Bacteria (23), we propose that pvs. citri and phaseoli remain temporarily as pathovars of $X$. campestris until more DNA similarity information is available concerning their relationship to $X$. campestris and other xanthomonads.

Xanthomonads of uncertain classification. Confusion on a large scale may potentially be caused by renaming xanthomonads to more accurately approximate their phylogenetic relationships. This confusion results when some xanthomonads are renamed on the basis of new information, while others are left behind in their current classifications, usually as pathovars of $X$. campestris, due to insufficient information. The result is that pathovars of $X$. campestris, rather than reflecting actual phylogenetic relationships also include xanthomonads placed in that group only because of lack of information. One suggestion is to correct this problem for pathologists by creating an artificial neutral taxon as a repository for all pathovars that are inadequately described. This taxon should be reserved for current and future xanthomonads whose descriptions are inadequate for further classification but cause important plant diseases. Possibly, a name such as $X$. phyllovora, carrying no indication of host specificity, may be useful for this "temporary" file. An artificial taxon may be useful for several to many years, until enough information has been gathered that all the current pathovars of $X$. campestris are moved into phylogenetically acceptable taxons. Such epithets may also have long-term usefulness for newly discovered xanthomonads that have not yet been described adequately for more precise identification. While the former suggestion is interesting, we seek comment from other pathologists on the concept. If acceptable, a brief description of X. phyllovora could be published in the International Journal of Systematic Bacteriology.

Summary. A summary of the names that we propose be rejected and accepted is presented in Tables 1 and 2, respectively. We point out that the newly suggested names such as $X$. exitiosa, $X$. hederea, and $X$. juglandis are suggestions and not formal proposals. A formal proposal must be published in the International Journal of Systematic Bacteriology. These recommendations have been discussed and approved by the Bacteriology Committee of APS. We, therefore, recommend to the editors of Phytopathology, Plant Disease, Molecular Plant-Microbe Interactions, and APS Press that authors be advised to follow these recommendations, until further data are forthcoming and evaluated. These choices are generally based upon the date of the original description following Rules 23a, 24a and b, and 26a of Section 5 (Priority and Publication of Names) of the International Code of Nomenclature (23).

\section{LITERATURE CITED}

1. Berthier, Y., Verdier, V., Guesdon, J. L., Chevier, D., Denis, J. B., Decoux, G., and Lemattre, M. 1993. Characterization of Xanthomonas campestris pathovars by rRNA gene restriction patterns. Appl. Environ. Microbiol. 59:851-859.

2. Bouzar, H., Jones, J. B., Stall, R. E., Hodge, N. C., Minsavage, G. V., Benedict, A. A., and Alvarez, A. M. 1994. Physiological, chemical, serological, and pathogenic analyses of a worldwide collection of Xanthomonas campestris pv. vesicatoria strains. Phytopathology 84:663-671.

3. Doidge, E. M. 1920. A tomato canker. J. Dep. Agric. Union S. Afr. 1: 718-721.

4. Dye, D. W., Bradbury, J. F., Goto, M., Hayward, A. C., Lelliot, R. A., and Schroth, M. N. 1980. International standards for naming pathovars of phytopathogenic bacteria and a list of pathovar names and pathotype strains. Rev. Plant Pathol. 59:153-168.

5. Egel, D. S., Graham, J. H., and Stall, R. E. 1991. Genomic relatedness of Xanthomonas campestris strains causing diseases of citrus. Appl. Environ. Microbiol. 57:2724-2730.

6. Gabriel, D. W., Kingsley, M. T., Hunter, J. E., and Gottwald, T. 1989. Reinstatement of Xanthomonas citri (ex Hasse) and X. phaseoli (ex Smith) to species and reclassification of all $X$. campestris pv. citri strains. Int. J. Syst. Bacteriol. 39:14-22.

7. Gardan, L., Bollet, C., Abu Giiorrah, M., Grimont, P. A. D., and Grimont, F. 1992. DNA relatedness among pathovar stains of Pseudomonas syringae subsp. savastanoi Janse (1982) and proposal of Pseudomonas savastanoi sp. nov. Int. J. Syst. Bacteriol. 42:606-612.

8. Gardan, L., Hussain, S., and Grimont, P. A. D. 1997. DNA relatedness among pathovars of $P$. syringae and related bacteria. Pages 445-448 in: Developments in Plant Pathology, Vol. 9: Pseudomonas syringae Pathovars and Related Pathogens. K. Rudolph, T. J. Burr, J. W. Mansfield, D. Stead, A. Vivian, and J. von Kietzell, eds. Kluwer Academic Publishers, Boston.

9. Gardan, L., Shafik, H., Belouis, S., Broch, R., Grimont, R., and Grimont, P. A. D. 1999. DNA relatedness among the pathovars of Pseudomonas syringae and description of Pseudomonas tremae sp. nov. and Pseudomonas cannabina sp. nov. (Ex. Sutic and Dowson, 1959). Int. J. Syst. Bacteriol. 49:469-478.

10. Gardner, M. W., and Kendrick, J. B. 1921. Bacterial spot of tomato. J. Agric. Res. 21:123-156.

11. Hartung, J. S., and Civerolo, E. L. 1987. Genomic fingerprints of Xanthomonas campestris pv. citri strains from Asia, South America, and Florida. Phytopathology 77:282-285.

12. Hartung, J. S., and Civerolo, E. L. 1989. Restriction fragment length polymorphisms distinguish Xanthomonas campestris strains isolated from Florida citrus nurseries from $X$. c. pv. citri. Phytopathology 79:793-799.

13. Hauben, L., Vauterin, L., Swings, J., and Moore, E. R. B. 1997. Comparison of $16 \mathrm{~S}$ ribosomal DNA sequences of all Xanthomonas species. 
Int. J. Syst. Bacteriol. 47:328-335

14. Hildebrand, D. C., Palleroni, N. J., and Schroth, M. N. 1990. Deoxyribonucleic acid relatedness of 24 xanthomonad strains representing 23 Xanthomonas campestris pathovars and Xanthomonas fragariae. J. Appl. Bacteriol. 68:263-269.

15. Hildebrand, D. C., Schroth, M. N., and Sands, D. C. 1988. Pseudomonas, 2nd ed. Pages 60-80 in: Laboratory Guide for Identification of Plant Pathogenic Bacteria. N. W. Schaad, ed. The American Phytopathological Society, St. Paul, MN.

16. Johnson, J. L. 1984. Similarity analyses of DNAs. Pages 655-682 in: Methods for General and Molecular Bacteriology. P. Gerhardt, R. G. E. Murray, W. A. Woods, and N. R. Krieg, eds. American Society for Microbiology, Washington, DC.

17. Lapage, S. P., Clark, W. A., Lessel, E. F., Seeliger, H. P. R., and Sneath, P. H. A. 1973. Proposed revision of the International Code of Nomenclature of Bacteria. Int. J. Syst. Bacteriol. 23:83-108.

18. Lazo, G. R., Roffey, R., and Gabriel, D. W. 1987. Pathovars of Xanthomonas campestris are distinguishable by restriction fragment length polymorphism. Int. J. Syst. Bacteriol. 37:214-221.

19. Ovod, V., Rudolph, K., and Krohn, K. 1997. Serological classification of Pseudomonas syringae pathovars based on monoclonal antibodies towards the lipopolysaccharide O-chains. Pages 526-531 in: Developments in Plant Pathology, Vol. 9: Pseudomonas syringae Pathovars and Related Pathogens. K. Rudolph, T. J. Burr, J. W. Mansfield, D. Stead, A. Vivian, and J. von Kietzell, eds. Kluwer Academic Publishers, Boston.

20. Palleroni, N. J., Hildebrand, D. C., Schroth, M. N., and Hendson, M. 1993. Deoxyribonucleic acid relatedness of 21 strains of Xanthomonas species and pathovars. J. Appl. Bacteriol. 75:441-446.

21. Ridé, M., and Ridé, S. 1978. Xanthomonas populi (ex Ridé, 1958) sp. nov., nom. rev. Int. J. Syst. Bacteriol. 42:652-653.

22. Skerman, V. B. D., McGowan, V., and Sneath, P. H. A. 1980. Approved list of bacterial names. Int. J. Syst. Bacteriol. 30:225-420.

23. Sneath, P. H. A., ed. 1992. International Code of Nomenclature of Bacteria and Statutes of the International Committee on Systematic Bacteriology and Statutes of the Bacteriology and Applied Microbiology Section of The International Union of Microbiological Societies. American Society of Microbiology, Washington, DC.

24. Stackebrand, E., and Goebel, B. M. 1994. Taxonomic note: A place for DNA-DNA reassociation and $16 \mathrm{~S}$ rRNA sequence analysis in the present species definition in bacteriology. Int. J. Syst. Bacteriol. 44:846-849.

25. Stall, R. E., Beaulieu, C., Egel, D. S., Hodge, N. C., Leite, R. P., Minsavage, G. V., Bouzar, H., Jones, J. B., Alvarez, A. M., and Benedict, A. A. 1994. Two genetically diverse groups of strains are included in Xanthomonas campestris pv. vesicatoria. Int. J. Syst. Bacteriol. 44:47-53.

26. Starr, M. P., and Garces, O. C. 1950. El agente causante de la gomosis bacterial del pasto imperial en Colombia. Rev. Fac. Nac. Agron. Medellin 12:73-83.

27. Swings, J., Van den Mooter, M., Vauterin, L., Hoste, B., Gillis, M., Mew, T. W., and Kersters, K. 1990. Reclassification of the causal agents of bacterial blight (Xanthomonas campestris pv. oryzae) and bacterial leaf streak (Xanthomonas campestris pv. oryzicola) of rice as pathovars of
Xanthomonas oryzae (ex Ishiyama 1922) sp. nov., nom. rev. Int. J. Syst. Bacteriol. 40:301-311.

28. Thaveechai, N., and Schaad, N. W. 1986. Serological and electrophoretic analysis of a membrane protein extract of Xanthomonas campestris pv. campestris from Thailand. Phytopathology 76:139-147.

29. Van den Mooter, M., and Swings, J. 1990. Numerical analysis of 295 phenotypic features of 266 Xanthomonas strains and related strains and an improved taxonomy of the genus. Int. J. Syst. Bacteriol. 40:348-369.

30. Vauterin, L., Hoste, B., Kersters, K., and Swings, J. 1995. Reclassification of Xanthomonas. Int. J. Syst. Bacteriol. 45:472-489.

31. Vauterin, L., Hoste, B., Yang, P., Alvarez, A., Kersters, K., and Swings, J. 1993. Taxonomy of the genus Xanthomonas. Pages 157-192 in: Xanthomonas. J. G. Swings and E. L. Civerolo, eds. Chapman \& Hall, London.

32. Vauterin, L., Swings, J., and Kersters, K. 1991. Grouping of Xanthomonas campestris pathovars by SDS-PAGE of proteins. J. Gen. Microbiol. 137:1677-1687.

33. Vauterin, Y., Yang, P., Hoste, B., Vancanneyt, M., Civerolo, E. L., Swings, J., and Kersters, K. 1991. Differentiation of Xanthomonas campestris pv. citri strains by sodium dodecyl sulfate-polyacrylamide gel electrophoresis of proteins, fatty acid analysis, and DNA-DNA hybridization. Int. J. Syst. Bacteriol. 41:535-542

34. Vera Cruz, C. M., Gosselé, F., Kersters, K., Segers, P., Van den Mooter, M., Swings, J., and De Ley, J. 1984. Differentiation between Xanthomonas campestris pv. oryzae, $X$. campestris pv. oryzicola and the brown blotch pathogen on rice by numerical analysis of phenotypic features and protein gel electrophoregrams. J. Gen. Microbiol. 130:2983-2999.

35. Wayne, L. G., Brenner, D. J., Colwell, R. R., Grimont, P. A. D., Kandler, O., Krichevsky, M. I., Moore, L. H., Moore, W. E. C., Murray, R. G. E., Stakebrandt, E., Starr, M. P., and Trüper, H. G. 1987. Report of the ad hoc committee on the reconciliation of approaches to bacterial systematics. Int. J. Syst. Bacteriol. 37:463-464.

36. Willems, A., Gillis, M., Kersters, K., Van den Broeke, L., and De Ley, J. 1987. Transfer of Xanthomonas ampelina Panagopoulos 1969 to a new genus, Xylophilus gen. nov., as Xylophilus ampelinus (Panagopoulos 1969) comb. nov. Int. J. Syst. Bacteriol. 37:422-430.

37. Young, J. M., Bradbury, J. F., Gardan, L., Gvozdyak, R. I., Stead, D. E., Takikawa, Y., and Vidaver, A. K. 1991. Comment on the reinstatement of Xanthomonas citri (ex Hasse 1915) Gabriel et al. 1989 and X. phaseoli (ex Smith 1897) Gabriel et al. 1989: Indication of the need for minimal standards for the genus Xanthomonas. Int. J. Syst. Bacteriol. 41:172-177.

38. Young, J. M., Dye, D. W., Bradbury, J. F., Panagopoulos, C. G., and Robbs, C. F. 1978. A proposed nomenclature and classification for plant pathogenic bacteria. N.Z. J. Agric. Res. 21:153-177.

39. Young, J. M., Dye, D. W., Bradbury, J. F., Panagopoulos, C. G., and Robbs, C. F. 1978. The use of the term "pathovar" in the classification of plant pathogenic bacteria. Pages 354-363 in: Proceedings of the IV International Conference on Plant Pathogenic Bacteria Vol. II. Station De Pathologie Vegetale et Phytobacteriologie, INRA, Angers, France, ed.

40. Young, J. M., Saddler, G. S., Takikawa, Y., DeBoer, S. H., Vauterin, L., Gardan, L., Gvozdyak, R. I., and Stead, D. E. 1996. Names of plant pathogenic bacteria 1864-1995. Rev. Plant Pathol. 75:721-763. 